\title{
Technological and sensory pork quality in relation to muscle and drip loss protein profiles
}

\author{
Elżbieta Żelechowska • Wiesław Przybylski • \\ Danuta Jaworska • Véronique Santé-Lhoutellier
}

Received: 9 May 2011/Revised: 20 February 2012/ Accepted: 28 February 2012/Published online: 16 March 2012

(C) The Author(s) 2012. This article is published with open access at Springerlink.com

\begin{abstract}
Fifteen meat samples collected from pigs (Neckar hybrid line) were selected from 75 animals on the basis of their technological quality traits, and the samples were classified as normal, PSE, and acid meat. Sensory analysis was performed on the three meat categories. Total meat protein and drip loss protein were analyzed by electrophoresis (SDS-PAGE), mass spectrometry, and image analysis. From a sensory point of view, PSE meat was characterized by lower color intensity, and acid meat was characterized by the lowest score of juiciness. Certain soluble proteins derived from the drip loss were associated with meat quality, especially phosphoglucomutase and the $B$ chain of hemoglobin in the case of PSE and acid meat. Low quantities of myofibrillar proteins (myosin LC1, troponin $\mathrm{T}(\mathrm{TnT})$ and troponin $\mathrm{C}(\mathrm{TnC})$ ) in meat with high glycogen levels and low $\mathrm{pH}$ levels resulted in a higher rate of proteolysis of myofibrillar proteins due to higher enzymatic proteolysis activity in the meat. The results of this study showed that the $\mathrm{TnC} / \mathrm{TnI}$ ratio may be a pertinent marker of postmortem muscle metabolism and that this ratio is related to textural properties.
\end{abstract}

Electronic supplementary material The online version of this article (doi:10.1007/s00217-012-1705-z) contains supplementary material, which is available to authorized users.

E. Żelechowska $(\bowtie) \cdot$ W. Przybylski · D. Jaworska Department of Catering Technology and Food Hygiene, Faculty of Human Nutrition and Consumer Sciences, Warsaw University of Life Sciences, SGGW, Nowoursynowska 159c, 02-776 Warsaw, Poland e-mail: zelechowska.elzbieta@wp.pl

V. Santé-Lhoutellier INRA, UR370 QuaPA, 63122 Saint-Genès-Champanelle, France
Keywords Pork - Electrophoresis - PSE meat . Acid meat $\cdot$ Drip loss

\section{Introduction}

Pork represents $60 \%$ of the total amount of meat $(70 \mathrm{~kg} /$ capita/year) consumed in Poland and half of this meat is sold as culinary fresh meat. Therefore, it is important to satisfy the consumer's expectations of high quality products. The properties of meat are strictly dependent on the range and intensity of glycolytic and proteolytic changes, which are affected by the enzymes present in the sarcoplasmic fraction of meat proteins. The amount and activity of enzymes in the glycolysis pathway, and level of muscle glycogen at slaughter are conditioned by the range of glycolytic changes, which, in turn, influence the decrease in meat $\mathrm{pH}$ levels and activation of proteolytic enzymes. As a result of the enzyme activity in meat, new components with molecular weights of 110,95 , and $55 \mathrm{kDa}$ as well as molecular weights less than $30 \mathrm{kDa}$ appear in meat and they are indicators of the degree of proteolysis of myofibrillar proteins [1-4]. Generation of a protein/polypeptide profile determines many traits that influence the technological (water capacity, color intensity, color homogeneity, stability, losses in cooking, and losses in processes) and sensory qualities (appearance, tenderness, juiciness, flavor, and odor) of pork meat.

Several studies have referred to meat quality. In these studies, researchers tried to find a critical factor influencing drip loss [5-11] and tenderness $[6,11,12]$ or to identify biochemical mechanisms responsible for meat color variability $[11,13,14]$.

Drip loss can be predicted on the basis of $\mathrm{pH}$ and temperature measurements within the first $2 \mathrm{~h}$ postmortem [5]. 
The rate of postmortem $\mathrm{pH}$ decline influences the rate of activation/autolysis of $\mu$-calpain, which may have a pivotal role in the degradation of proteins that tie the myofibril to the sarcolemma (such as desmin and talin) [10], which ultimately affect drip loss and the rate of postmortem tenderization [6-8]. Desmin is likely to be a protein marker for drip loss because its levels are higher in muscle with low drip loss [9]. Another potential marker is creatine phospho kinase (CPK). A high level of CPK has been observed in muscle with high drip loss [9]. Differences in water-holding capacity may also be related to differences in myosin $\mathrm{HC}$ isoforms [6, 11, 15, 16]. Muscles with the lowest percentage of myosin $\mathrm{HC} \mathrm{IIb}$ and greatest percentage of myosin HC I have less drip loss [6, 17] and better tenderness, and these myosin isoform percentages in muscles are positively related to color characteristics [11]. Lactate dehydrogenase (LDH) also affects the color stability of muscles. LDH has a specific role in metmyoglobin reduction by regenerating $\mathrm{NADH}$, which affects color stability $[13,14]$.

Moreover, the $\mathrm{RN}^{-}$gene affects meat quality [18-20]. Postmortem meat is a carrier of the $\mathrm{RN}^{-}$gene and this meat is called acid meat because it has a lower ultimate $\mathrm{pH}$. Although these genes have been eliminated from the selection lines in several countries, PSE (pale, soft, exudative) and acid meat is still found (Niemyjski, personal communication).

There is currently no data on the characteristic of the protein/polypeptide profile in PSE, acid, and normal meat. Joo et al. [21] analyzed the protein compositions of PSE, RSE (reddish-pink, soft, exudative), RFN (reddish-pink, firm, non-exudative), and DFD (dark, firm, dry) meat and they reported that the degree of protein denaturation affects the drip loss and meat color. The aim of the present study was to find differences in the protein/polypeptide profile among PSE, acid, and normal meat and to analyze their relations with technological and sensory qualities. This pilot study will help to better understand the influence of range and intensity of glycolytic and proteolytic changes in meat on its culinary and technological suitability.

\section{Materials and methods}

Raw material

This study was performed on 15 pigs previously selected from 75 animals (pure Neckar hybrid line). The Neckar line was produced by the PenArLan French Company to be crossbreed with the Pietrain breed. The Neckar line is characterized by high daily gain and good carcass conformation (especially a large area of the loin "eye"), which enables the production of heavy pigs with high meatiness.
Pigs originating from the herds were included in the program of elimination of disadvantageous genes' influence on meat quality $\left(\mathrm{RYR}^{\mathrm{T}}\right.$ and $\left.\mathrm{RN}^{-}\right)$. Among these 75 pigs, 5 produced PSE meat and 5 produced meat with a low ultimate $\mathrm{pH}$. Out of the remaining 65 pigs were selected 5 animals similar to the average of the group (typical for normal meat). All animals came from the same farm and were kept under identical environmental conditions.

All animals were transported to the meat plants with the same transport conditions. The fatteners were slaughtered at a meat plant in Stanisławowo (Poland) in accordance with legally binding procedures, including automatic electric stunning and bleeding in a horizontal position. After slaughter, the backfat thickness and Longissimus muscle thickness (at the height of the last rib) were measured using a CGM apparatus (Sydel, France), and the percentage of lean meat content was estimated according to Borzuta [22].

Meat quality traits

The meat quality parameters were evaluated in the samples taken from the Longissimus muscle. The samples were taken at the height of the last rib after the carcasses were cooled for $24 \mathrm{~h}$ after the slaughter. At the meat processing plants, $\mathrm{pH}$ measurements were taken at $45 \mathrm{~min}$ and $24 \mathrm{~h}$ postmortem. The samples were transported in ice-chilled polystyrene refrigerators at $4{ }^{\circ} \mathrm{C}$. All remaining analyses were made at the laboratory. The $\mathrm{pH}$ value was measured at $1\left(\mathrm{pH}_{1}\right), 24\left(\mathrm{pH}_{24}\right)$, and $48\left(\mathrm{pH}_{48}\right) \mathrm{h}$ after slaughter with a WTW 330i pH meter (Germany). Meat color was measured according to the CIE L*a*b* system using a CR310 Minolta Chroma Meter with a $\mathrm{D}_{65}$ light source (Osaka, Japan) at $48 \mathrm{~h}$ postmortem. The loin chops (length of $2 \mathrm{~cm}$ ) were cut and bloomed for $1 \mathrm{~h}$ at $4{ }^{\circ} \mathrm{C}$ with no surface covering prior to color measurements (in triplicate). The drip loss percentage was determined $48 \mathrm{~h}$ after slaughter according to Prange et al. [23]. Muscle glycogen, glucose, and glucose-6-phosphate were determined according to Dalrymple and Hamm [24], and lactate was determined according to Bergmeyer [25]. The glycolytic potential (GP) was calculated according to Monin and Sellier [26]. Drip and meat samples were frozen at $-80{ }^{\circ} \mathrm{C}$ until subsequent analysis.

Meat selection

The acid, PSE, and normal meat samples were grouped according to $\mathrm{pH}_{1}$ and $\mathrm{pH}_{24}$ as follows: PSE meat had $\mathrm{pH}_{1}$ values less than 6.0; acid meat had $\mathrm{pH}_{1}$ values greater than or equal to 6.0 and $\mathrm{pH}_{24}$ values less than 5.5; and normal meat had $\mathrm{pH}_{1}$ values greater than 6.0 and $\mathrm{pH}_{24}$ values greater than 5.5. A total of five samples per type of meat (acid, PSE, and normal) were selected according to the 
method presented by Koćwiń-Podsiadła et al. [27]. In each group, there were three gilts and two hogs (castrated males).

\section{Sensory analysis}

The eating qualities were evaluated in meat aged $96 \mathrm{~h}$. A meat sample (approximately $600 \mathrm{~g}$ ) was heated in a salt solution $(0.8 \% \mathrm{NaCl})$ to reach a core temperature of $72{ }^{\circ} \mathrm{C}$ according to Baryłko-Pikielna et al. [28]. After cooking, the meat was cooled down at room temperature $\left(24{ }^{\circ} \mathrm{C}\right)$ and prepared for sensory assessment.

The meat samples were cut into portions (cubes) of approximately equal size and weight (ca. $25 \mathrm{~g}$ ), and the samples were then placed in plastic, odorless, and disposable boxes covered with lids. The flavor, color intensity, color homogeneity, fat perception, texture, and juiciness were evaluated according to the sensory QDA method [29] with an unstructured, linear graphical scale of $100 \mathrm{~mm}$, which was later converted to numerical values (0-10 conventional units c.u.). The assessment was performed by a formally trained panel of 10 people (3-8 years of sensory evaluation practices). All samples were separately coded for the assessment using three digit codes and were passed in random order to avoid the carryover effect. The condition and assessment mode were determined in accordance with Meilgaard et al. [30].

Sodium dodecyl sulfate polyacrylamide gel electrophoresis (SDS-PAGE)

SDS-PAGE of drip loss and muscular tissue was performed according to the method of Bollag and Edelstein [31] using the STANDARD system (Kucharczyk TE, Poland). Proteins were resolved on a $12 \%$ separation gel and $5 \%$ stacking gel. Myofibrillar proteins were extracted from $20 \mathrm{mg}$ of muscle, homogenized with $800 \mu \mathrm{L}$ of a Tris- $\mathrm{HCl}$ buffer (pH 6.8) containing $0.375 \mathrm{M}$ 2-mercaptoethanol, $3 \% \mathrm{SDS}, 8 \mathrm{M}$ urea, and $2 \mathrm{M}$ thiourea. Muscle protein concentration was determined as total nitrogen using the AOAC method [32]. The concentration of soluble protein from the drip loss was determined using the Biuret procedure. Myofibrillar and soluble proteins from the drip loss were dissolved $1 / 1(\mathrm{v} / \mathrm{v})$ in Tris- $\mathrm{HCl}$ sample buffer $(\mathrm{pH}$ 6.8) containing $0.375 \mathrm{M}$ 2-mercaptoethanol, $3 \%$ SDS, $8 \mathrm{M}$ urea, $2 \mathrm{M}$ thiourea, and $0.05 \%$ bromophenol blue. The mixture was then heated for $3 \mathrm{~min}$ at $95{ }^{\circ} \mathrm{C}$, and $25 \mu \mathrm{L}$ of the mixture was then placed in each well. Gels were first run for approximately $1 \mathrm{~h}$ at $75 \mathrm{~V}$ followed by $5 \mathrm{~h}$ at 150 V. Gels were stained with Coomassie Brilliant Blue R250. Image analysis and quantification were performed using GelScan v. 1.45 software (Kucharczyk TE, Poland).
Protein identification by mass spectrometry

Coomassie-stained spots of interest (W12) were manually removed using pipette tips. The gel spots were then destained with $100 \mu \mathrm{L}$ of $25 \mathrm{mM} \mathrm{NH}_{4} \mathrm{HCO}_{3}$ with acetonitrile $95 / 5(\mathrm{v} / \mathrm{v})$ for $30 \mathrm{~min}$ followed by two washes in $100 \mu \mathrm{L}$ of $25 \mathrm{mM} \mathrm{NH}_{4} \mathrm{HCO}_{3}$ with acetonitrile 50/50 (v/v). The gel spots were then dehydrated in $100 \%$ acetonitrile. Gel spots were completely dried using a Speed Vac before trypsin digestion at $37{ }^{\circ} \mathrm{C}$ for $5 \mathrm{~h}$ with $15 \mu \mathrm{L}$ of trypsin (10 ng/ $\mu \mathrm{L}$; V5111, Promega) in $25 \mathrm{mM} \mathrm{NH} \mathrm{HCO}_{3}$. Peptide extraction was optimized by adding $8 \mu \mathrm{L}$ of acetonitrile, followed by $10 \mathrm{~min}$ of sonication. Peptide mass identification of trypsin-digested spots was attempted using nano LC-ion trap MS/MS analysis. HPLC was performed with an ULTIMATE LC SYSTEM combined with a Famos autosampler and Switchos II microcolumn switching for preconcentration (LC Packings, Amsterdam, The Netherlands). The supernatant-containing peptides $(6 \mu \mathrm{L})$ was loaded on the PEPMAP C18 column $(5 / 75 \mu \mathrm{m}$ ID/15 cm column; Dionex, Labège, France) using a preconcentration step in a microprecolumn cartridge $(300 \mu \mathrm{m} \mathrm{ID} / 1 \mathrm{~mm})$ at $30 \mu \mathrm{L} / \mathrm{min}$. After $3 \mathrm{~min}$, the precolumn was connected to the separating column and the gradient was commenced at $200 \mathrm{~nL} / \mathrm{min}$. The following buffers were used: (A) $5 \%$ $\mathrm{ACN}$ and $0.5 \% \mathrm{HCOOH}$ in water; and (B) $5 \% \mathrm{H}_{2} \mathrm{O}$ and $0.5 \% \mathrm{HCOOH}$ in $\mathrm{ACN}$. A linear gradient from 10 to $90 \%$ B for 45 min was applied. For ion trap MS, an LCQ DECA with a nanoelectrospray interface (Thermo Fisher Scientific, Les Ulis, France) was used. Ionization $(2.2 \mathrm{kV}$ ionization potential) was performed with a liquid junction and a noncoated capillary probe (New Objective, Cambridge, USA). Peptide ions were analyzed by the data-dependent "triple play" method as follows: (1) full MS scan $(\mathrm{m} / \mathrm{z}, 400-1,400)$, (2) zoomscan (scan of the major ion with larger resolution), and (3) MS/MS of this ion. Identification of peptides was performed with Mascot 2.2 restricting the taxonomy to mammalia (20080417 and 1177111 sequences) in the National Center for Biotechnology Information (NCBI) $\mathrm{nr}$ protein database. Mass deviation tolerance was set at $1.5 \mathrm{Da}$ for parent ions and 0.8 for fragment ions. Protein identification was validated when at least two peptides originating from one protein showed significant identification scores.

Data analysis

All values were reported as the means \pm standard deviation (SD). A one-way analysis of variance of the type of meat as a fixed effect was performed. Pearson correlation coefficients between meat quality parameters and protein quantification obtained by electrophoresis were measured. Statistical analysis was conducted with Statistica 9.0 software (Stat Soft, Inc. version 9.0). 


\section{Results and discussion}

Meat quality

All the pigs showed a high level of meatiness $(58.5 \%)$ with a medium hot carcass weight of $90 \mathrm{~kg}$. This carcass characteristic is close to the one of fatteners obtained from crossing Polish Landrace and Polish Large White sows with P76-PenArLan hybrid boars and which were used to obtain the Neckar line [33].

Meat quality defects are strongly linked to major genes in pigs and environmental conditions. Despite that the pigs originated from herds belonging to the program of elimination of disadvantageous genes' influence on meat quality $\left(\mathrm{RYR} 1^{\mathrm{T}}\right.$ and $\mathrm{RN}^{-}$), approximately $10 \%$ of the 75 meat samples were classified as PSE and a similar percentage was found for acid meat. However, PSE meat and meat with low $\mathrm{pH}$ levels have been observed in races lacking these two genes [17, 19, 34, 35], which may have been due to stress conditions of preslaughter trade, slaughter, and feeding $[19,36]$. The electrical low voltage stunning may contribute to the occurrence of PSE meat [37, 38]. The meat quality parameters for acid, PSE, and normal meat are shown in Table 1 . The rate of $\mathrm{pH}\left(\mathrm{pH}_{1}\right)$ differed according to meat category. As expected, PSE had the highest rate of $\mathrm{pH}$ decline. The ultimate $\mathrm{pH}$ was the lowest for acid meat with PSE being in the middle between acid and normal meat. These results were in accordance with the higher GP measured in acid meat and confirmed the negative relationship between glycogen levels and ultimate $\mathrm{pH}$. Compared to the other meat types, more lactate was produced during postmortem glycolysis and fourfold more residual glycogen was present in postmortem acid meat (Table 1). Similar results were reported by Immonen [39] and Przybylski et al. [40] who reported that high glycogen content just after slaughter leads to a higher degree of acidification. At the same time, however, a considerable amount of residual glycogen was observed. Despite the absence of the $\mathrm{RN}^{-}$gene, there was relatively high GP in the studied groups. Resenvold et al. [36] reported that the level of glycogen at slaughter is largely dependent on animal nutrition. In addition, there have been recent reports about the impact of other genes on the level of glycogen and GP. Sieczkowska et al. [35] showed a significant effect of PKM2 gene (pyruvate kinase muscle gene in the glycolytic pathway that catalyzes the conversion of phosphoenolpyruvate into pyruvate, which is later reduced to lactate in anaerobic conditions) on GP, $\mathrm{pH}$, and drip loss. The average GP values reported by these authors for each of the three possible genotypes were similar to those obtained in this study. Moreover, Kamiński et al. [34] reported the effect of the DECR1 on GP, glycogen metabolism, and meat quality and the reported values of these parameters were similar to those obtained in the present study. DECR1 is a nuclear gene encoded by a mitochondrial enzyme that participates in the fatty acid beta-oxidation pathway. According to Stefanon et al. [41], DECR1 is involved in the control of fat and protein deposition. In Landrace pigs, Amills et al. [42] showed the effect of DECR1 on Longissimus thoracis pH, lightness, and redness of meat. Kamiński et al. [43] also showed the effects of DECR1 on the growth rate of Landrace boars.

With regard to the color parameters ( $\mathrm{L}^{*}, \mathrm{a}^{*}$, and $\left.\mathrm{b}^{*}\right)$, the luminosity of normal meat differed from the luminosity of the acid and PSE meat. Moreover, a lighter intensity of color was observed for the PSE and acid meat compared to the normal meat. Lightness of meat color is characteristic of PSE and acid meat [21] and is partly explained by the degree of $\mathrm{pH}$ decline [19, 20, 26, 27].

The drip loss varied according to postmortem metabolism as a result of ATP degradation and the rate of acidification, and the drip loss also varied with the chilling conditions. Compared to other studies in pigs [15, 21, 44], the measured drip loss remained low. The drip loss was lower than $3 \%$ in normal meat, and the increase was by about 1.08 and $0.71 \%$ for PSE and acid meat, respectively (Table 1). Among the quality classes, however, there was no significant difference in the size of drip loss. Similar ultimate $\mathrm{pH}$, glycogen level, and drip loss results were obtained by Josell et al. [19] in pigs carrying the $\mathrm{RN}^{-}$gene and pigs lacking the $\mathrm{RN}^{-}$gene. Similarly, Choe et al. [17] reported that the drip loss results in pigs at high and low GP with low lactic acid and varying ultimate $\mathrm{pH}$ levels are not significantly different. However, Van Oeckel et al. [44] reported a significant difference (approximately $20 \%$ ) in drip loss between normal and PSE meat.

\section{Sensory attributes}

The results of the sensory analysis are shown in Table 2. The three types of meat did not differ in terms of odor or color homogeneity. The PSE meat had lower color intensity, compared to the acid and normal meat. The juiciness was lower in the acid meat compared to the other meat types, and the tenderness did not differ between the studied materials (Table 2). The literature concerning the relationship between ultimate $\mathrm{pH}$ and tenderness and the relationship between ultimate $\mathrm{pH}$ and juiciness is controversial. Josell et al. [18] and Miller et al. [45] showed that meat with low $\mathrm{pH}$ is characterized by higher tenderness and juiciness, but Le Roy et al. [46] reported a negative effect of low ultimate $\mathrm{pH}$ on the tenderness of meat. Moreover, Toldrá and Flores [47] did not find any effect of ultimate $\mathrm{pH}$ on the tenderness or juiciness of meat. Josell et al. [18] reported that the higher tenderness and juiciness values of meat from pigs with higher GP $\left(\mathrm{RN}^{-}\right.$carriers) are 
Table 1 Meat quality traits from normal, PSE, and acid meat (Mean value \pm SD of five separate samples)

a,b,c Means with different superscript show significant differences (at $P \leq 0.05$ )

Table 2 Means of sensory attributes of cooked normal, PSE, and acid meat (Mean value \pm SD of five separate samples)

\footnotetext{
a,b Means with different superscript show significant differences $(P \leq 0.05)$
}

\begin{tabular}{|c|c|c|c|c|}
\hline & \multicolumn{4}{|c|}{ Meat quality classes } \\
\hline & Normal & PSE & Acid & $P$ \\
\hline $\mathrm{pH}_{1}$ & $6.68^{c} \pm 0.15$ & $5.89^{\mathrm{b}} \pm 0.07$ & $6.35^{\mathrm{a}} \pm 0.21$ & 0.01 \\
\hline $\mathrm{pH}_{24}$ & $5.64^{c} \pm 0.04$ & $5.46^{\mathrm{b}} \pm 0.08$ & $5.35^{\mathrm{a}} \pm 0.03$ & 0.01 \\
\hline $\mathrm{pH}_{48}$ & $5.61^{c} \pm 0.05$ & $5.44^{\mathrm{b}} \pm 0.08$ & $5.33^{\mathrm{a}} \pm 0.03$ & 0.01 \\
\hline Glycogen $(\mu \mathrm{mol} / \mathrm{g})$ & $3.3^{\mathrm{b}} \pm 1.09$ & $8.1^{\mathrm{a}} \pm 5.54$ & $12.9^{\mathrm{a}} \pm 2.31$ & 0.01 \\
\hline Lactate $(\mu \mathrm{mol} / \mathrm{g})$ & $104^{\mathrm{b}} \pm 7.80$ & $104^{\mathrm{b}} \pm 4.10$ & $116^{\mathrm{a}} \pm 5.40$ & 0.01 \\
\hline GP $(\mu \mathrm{mol} / \mathrm{g})$ & $111^{\mathrm{b}} \pm 8.50$ & $120^{\mathrm{b}} \pm 14.40$ & $142^{\mathrm{a}} \pm 6.15$ & 0.01 \\
\hline \multicolumn{5}{|l|}{ Color coordinates } \\
\hline $\mathrm{L}^{*}$ & $51.45^{\mathrm{b}} \pm 1.39$ & $54.34^{\mathrm{a}} \pm 2.84$ & $56.20^{\mathrm{a}} \pm 0.66$ & 0.01 \\
\hline$a^{*}$ & $15.84 \pm 0.97$ & $16.57 \pm 0.88$ & $16.37 \pm 1.33$ & NS \\
\hline$b^{*}$ & $4.69 \pm 0.22$ & $5.24 \pm 1.63$ & $5.92 \pm 0.63$ & NS \\
\hline Drip loss $(\%)$ & $2.89 \pm 0.86$ & $3.91 \pm 1.26$ & $3.60 \pm 0.82$ & NS \\
\hline
\end{tabular}

\begin{tabular}{|c|c|c|c|c|}
\hline \multirow{2}{*}{$\begin{array}{l}\text { Sensory attributes } \\
(0-10 \text { c.u. })\end{array}$} & \multicolumn{4}{|c|}{ Meat quality classes } \\
\hline & Normal & PSE & Acid & $P$ \\
\hline Odor of cooked meat & $7.7 \pm 0.27$ & $7.8 \pm 0.21$ & $8.0 \pm 0.22$ & NS \\
\hline Acid odor & $2.4 \pm 0.39$ & $2.4 \pm 0.12$ & $2.6 \pm 0.24$ & NS \\
\hline Fatty odor & $2.3 \pm 0.65$ & $3.0 \pm 1.00$ & $2.1 \pm 0.48$ & NS \\
\hline Another odor & $1.3 \pm 0.04$ & $1.4 \pm 0.12$ & $1.3 \pm 0.08$ & 0.06 \\
\hline Color intensity & $8.4^{\mathrm{a}} \pm 0.18$ & $8.1^{\mathrm{b}} \pm 0.12$ & $8.7^{\mathrm{a}} \pm 0.29$ & 0.02 \\
\hline Homogeneity of color & $8.1 \pm 0.45$ & $7.7 \pm 0.42$ & $8.5 \pm 0.46$ & 0.09 \\
\hline Tenderness & $7.4 \pm 1.09$ & $7.6 \pm 0.20$ & $7.6 \pm 1.01$ & NS \\
\hline Juiciness & $6.4^{\mathrm{b}} \pm 1.04$ & $6.9^{\mathrm{b}} \pm 0.25$ & $4.9^{\mathrm{a}} \pm 0.70$ & 0.02 \\
\hline Flavor of cooked meat & $7.6 \pm 0.47$ & $7.6 \pm 0.21$ & $7.6 \pm 0.36$ & NS \\
\hline Acid flavor & $2.2 \pm 0.43$ & $2.4 \pm 0.06$ & $2.5 \pm 0.39$ & NS \\
\hline Fatty flavor & $2.2 \pm 0.61$ & $2.7 \pm 0.59$ & $1.8 \pm 0.10$ & 0.10 \\
\hline Salty flavor & $1.8 \pm 0.24$ & $1.9 \pm 0.35$ & $2.0 \pm 0.27$ & NS \\
\hline Another flavor & $1.2 \pm 0.19$ & $1.5 \pm 0.06$ & $1.2 \pm 0.17$ & 0.08 \\
\hline Overall quality & $7.6 \pm 0.79$ & $7.3 \pm 0.53$ & $6.9 \pm 0.65$ & NS \\
\hline
\end{tabular}

attributed to the lower isometric tension and higher enzymatic activity, which increase the aging rate and myofibrillar fragmentation. 1 and 4 days postmortem meat from $\mathrm{RN}^{-}$carriers has significantly shorter myofibrils than meat from non-carriers $\mathrm{RN}^{-}$, which indicates higher proteolytic activity early postmortem in the $\mathrm{RN}^{-}$carriers. The flavor intensity and overall meat quality of the three meat types were similarly estimated.

\section{Protein markers of meat qualities}

\section{SDS-PAGE analysis of proteins from muscle tissue}

Figure 1 shows the protein profile from muscle tissue in normal, PSE, and acid meat. Table 3 shows the quantification for each protein band. Myosin, $\alpha$ actinin, actin, troponin $\mathrm{T}(\mathrm{TnT})$, tropomyosin, myosin $\mathrm{LC}$, troponin I
(TnI), troponin $\mathrm{C}(\mathrm{TnC})$, and myosin LC2 represented 15.3, $6.3,17.1,7.1,8.0,3.0,1.8,1.6$, and $3.3 \%$, respectively. The contents of these particular proteins were lower than the values determined by Kołczak et al. [48] for calf, heifer, and cow meat. The amount of these proteins was dependent on their origin and varied between 26.0 and $30.6 \%$ for myosin $\mathrm{HC}$, between 4.0 and $5.9 \%$ for $\alpha$ actinin, and between 18.5 and $21.8 \%$ for actin. The lower amount protein may be due to the fact that the tested samples in the present study contained both myofibrillar proteins and sarcoplasmic proteins, whereas the samples tested by Kołczak et al. [48] contained only purified myofibrillar proteins. Moreover, these differences may be due to the different origin of muscular tissue because the composition of meat protein is dependent on the age of animal, type of muscle, and time of frozen storage [48]. The residual products of the proteolytic changes during 
Fig. 1 SDS-PAGE of muscle protein isolated from the Longissimus thoracis muscle of normal, PSE, and acid meat.

The left lane corresponds to the molecular weight scale. The following abbreviations are used: $T n T$ troponin T, $T n I$ troponin $\mathrm{I}$, and $\mathrm{TnC}$ troponin $\mathrm{C}$
Table 3 Quantification of muscle proteins from the Longissimus thoracis muscle of normal, PSE, and acid meat (Mean value \pm SD of five separate samples) a,b Means with different superscript show significant differences $(P \leq 0.05)$. The following abbreviations are used $T n T$ troponin T, $T n I$ troponin I, $T n C$ troponin C

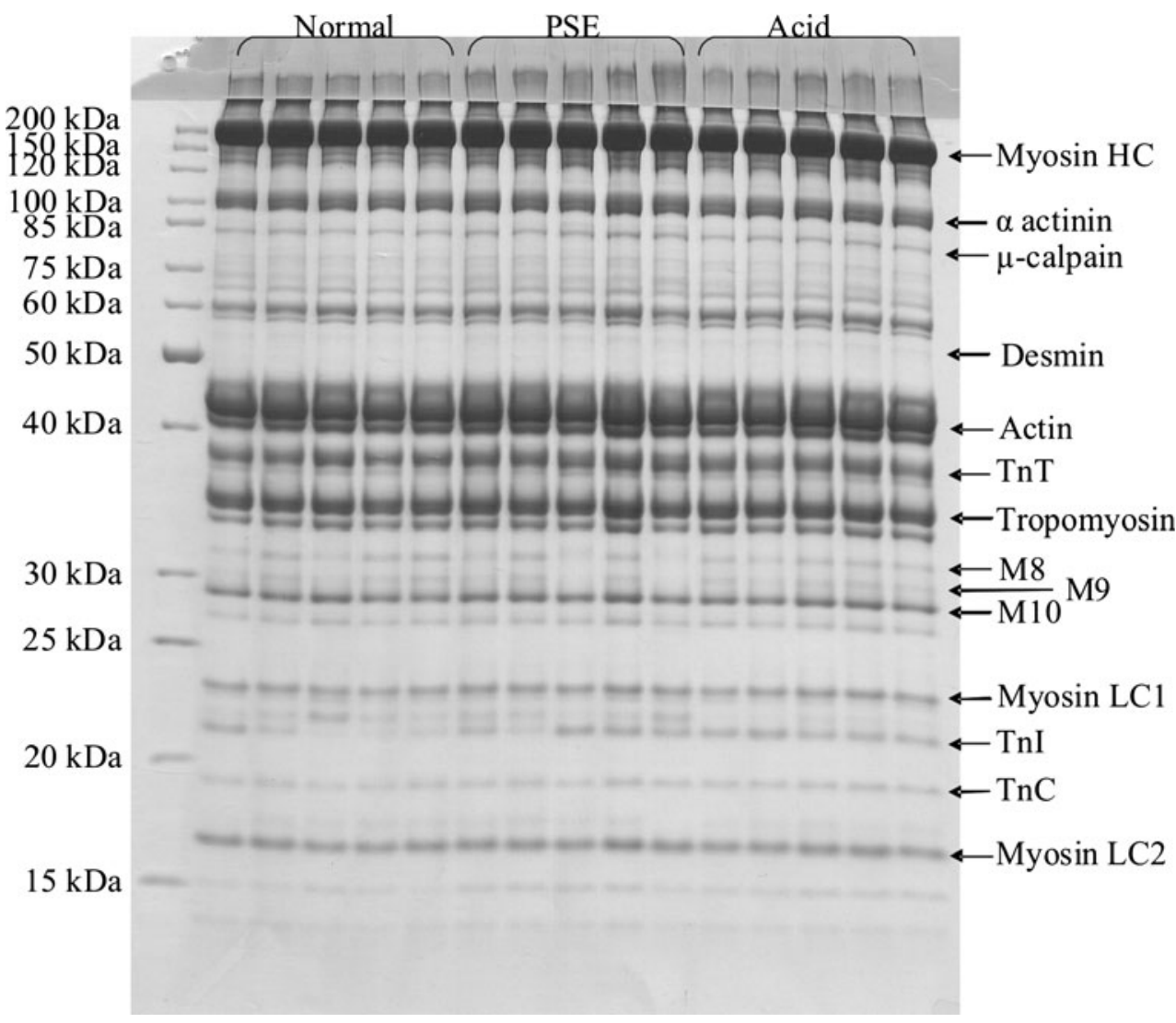

\begin{tabular}{|c|c|c|c|c|}
\hline & \multicolumn{4}{|l|}{ Meat quality } \\
\hline & Normal & PSE & Acid & $P$ \\
\hline Myosin & $15.86 \pm 0.42$ & $15.00 \pm 0.93$ & $14.98 \pm 0.19$ & NS \\
\hline$\alpha$-actinin & $6.56 \pm 0.40$ & $6.14 \pm 0.28$ & $6.24 \pm 0.38$ & NS \\
\hline$\mu$-calpain & $1.70^{\mathrm{b}} \pm 0.17$ & $2.36^{\mathrm{a}} \pm 0.34$ & $2.10^{\mathrm{a}} \pm 0.28$ & 0.01 \\
\hline Desmin & $0.72 \pm 0.18$ & $1.00 \pm 0.10$ & $1.02 \pm 0.26$ & 0.06 \\
\hline Actin & $17.46 \pm 0.30$ & $17.02 \pm 0.45$ & $16.80 \pm 0.89$ & NS \\
\hline TnT & $7.14 \pm 0.32$ & $7.28 \pm 0.27$ & $6.82 \pm 0.24$ & 0.06 \\
\hline Tropomyosin & $8.20 \pm 0.26$ & $7.92 \pm 0.22$ & $7.78 \pm 0.45$ & NS \\
\hline M8 & $1.70^{\mathrm{b}} \pm 0.14$ & $1.52^{\mathrm{a}} \pm 0.11$ & $1.42^{\mathrm{a}} \pm 0.08$ & 0.01 \\
\hline M9 & $0.68^{\mathrm{a}, \mathrm{b}} \pm 0.56$ & $0.48^{\mathrm{b}} \pm 0.36$ & $1.20^{\mathrm{a}} \pm 0.16$ & 0.04 \\
\hline M10 & $3.72^{\mathrm{b}} \pm 0.38$ & $3.34^{\mathrm{a}} \pm 0.09$ & $3.20^{\mathrm{a}} \pm 0.12$ & 0.01 \\
\hline Myosin LC1 & $3.14^{b} \pm 0.18$ & $2.98^{\mathrm{a}, \mathrm{b}} \pm 0.13$ & $2.84^{\mathrm{a}} \pm 0.15$ & 0.03 \\
\hline TnI & $1.30 \pm 0.93$ & $1.82 \pm 0.33$ & $2.18 \pm 0.29$ & 0.10 \\
\hline $\mathrm{TnC}$ & $1.84^{\mathrm{b}} \pm 0.21$ & $1.52^{\mathrm{a}} \pm 0.22$ & $1.54^{\mathrm{a}} \pm 0.09$ & 0.03 \\
\hline Myosin LC2 & $3.50 \pm 0.31$ & $3.36 \pm 0.09$ & $3.18 \pm 0.19$ & 0.10 \\
\hline
\end{tabular}

meat maturation were partitioned into polypeptides with molecular weights between 60 and $85 \mathrm{kDa}$ and polypeptides with an approximate molecular weight of $30 \mathrm{kDa}$. Some of the bands from the first group may be unautolyzed (80 kDa) $\mu$-calpain and its autolysis products (78 and $76 \mathrm{kDa}$ ) [7, 8, 10] (Table 3, Fig. 1). The 30-kDa polypeptides are the products of postmortem proteolysis of TnT
[7, 12]. Similar to results reported by Schäfer et al. [5], several non-identified products of protein degradation with molecular weights of 45,41 , and $39 \mathrm{kDa}$ were observed (Fig. 1).

A significant increase in the $\mu$-calpain band $(80 \mathrm{kDa})$ was observed in the PSE and acid meat samples (Table 3), which was in accordance with a previous study by Bee 
et al. [10] who reported a higher abundance of the unautolyzed $\mu$-calpain subunit in meat with lower $\mathrm{pH}$ values. In contrast, $\alpha$-actinin was stable in all three studied meat types, which was confirmed by the studies of Kołczak et al. [48] and Ahn et al. [49].

The M8 and M10 bands (approximately 31 and $29 \mathrm{kDa}$, respectively) were significantly more abundant in the normal meat than in the acid and PSE meat (Table 3). According to Lametsch et al. [50], proteins with approximate molecular weights of 31 and $29 \mathrm{kDa}$ are the proteolytic products of CK, which is proteolyzed into 3 fragments of 35, 31, and $29 \mathrm{kDa}$. Therefore, the higher abundance of M8 and M10 indicated a lower content of active CK, which was consistent with the results of Van de Wiel and Zhang [9], who observed a lower content of CK in meat with a normal rate of glycolysis.

In the present study, a significant difference in the amount of the M9 band, which corresponded to a protein with an approximate molecular weight of $30 \mathrm{kDa}$, was found among the three meat types (Table 3, Fig. 1) with the highest level observed in the acid meat. As stated by many authors, the $30-\mathrm{kDa}$ polypeptide is a degradation product of $\operatorname{TnT}[12,48,51]$, which was consistent with the present study because a lower abundance of TnT was observed in acid meat $\left(P_{\alpha} \leq 0.06\right)$ (Table 3). Degradation of TnT may simply be an indicator of overall postmortem proteolysis [12] that occurs faster at lower $\mathrm{pH}$ levels. Josell et al. [18] reported that higher enzymatic proteolysis activity in meat with low ultimate $\mathrm{pH}$ is confirmed by lower levels of nyosin LC1, TnT $(P \leq 0.06)$, and TnC. These proteins can be degraded by cathepsin, which is more active at low pH levels. Gil et al. [52] demonstrated that the maximum activity of cathepsin $\mathrm{B}+\mathrm{L}$ occurs in PSE meat and that the lowest activity of this enzyme occurs in DFD.

\section{SDS-PAGE analysis of protein from drip loss}

Figure 2 presents the protein profile of the drip loss from normal, PSE, and acid meat, and Table 4 shows the quantification of each band. Among the identified proteins, the following proteins were the most abundant: glyceraldehyde-3-phosphate dehydrogenase/lactate dehydrogenase (GAPDH/LDH), $14.9 \%$; enolase (EN), $11.9 \%$; aldolase (ALD), $11.0 \%$; creatine kinase/phosphoglycerate kinase (CK/PGAK), $9.9 \%$; and pyruvate kinase/phosphoglucose isomerase (PK/PGI), $9.1 \%$. This protein profile was similar to the one obtained by Pérez and Ruiz [53] for muscular protein from raw pork ham.

The protein profile of the drip loss showed small variations among the three types of meat. Only the W12 band was different between the three meat types because it was found in greater quantity in the PSE and acid meat than in

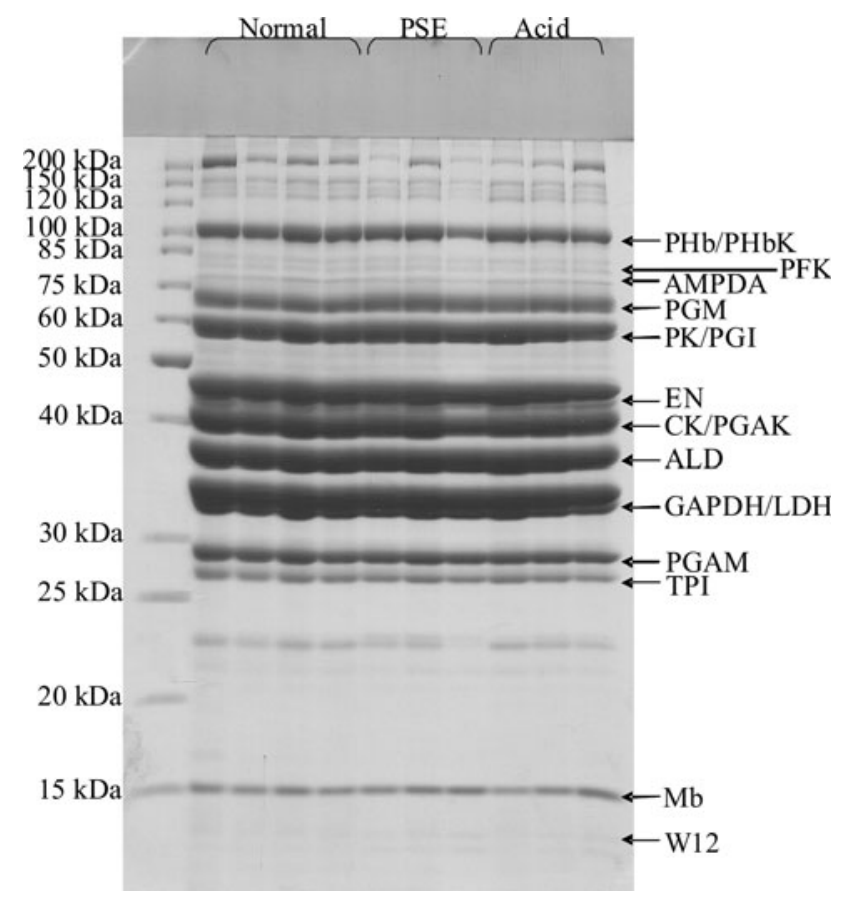

Fig. 2 SDS-PAGE of soluble proteins in the drip loss from the Longissimus thoracis muscle of normal, PSE, and acid meat. The left lane corresponds to the molecular weight scale. The following abbreviations are used: $P H b / P H b K$ phosphorylase b/phosphorylase $\mathrm{b}$ kinase, $P F K$ phosphofructokinase, AMPDA AMP deaminase, $P G M$ phosphoglucomutase, $P K / P G I$ pyruvate kinase/phosphoglucose isomerase, $E N$ enolase, $C K / P G A K$ creatine kinase/phosphoglycerate kinase, $A L D$ aldolase, $G A P D H / L D H$ glyceraldehyde-3-phosphate dehydrogenase/lactate dehydrogenase, PGAM phosphoglycerate mutase, TPI triosephosphate isomerase and $M b$ myoglobin

the normal meat (Table 4, Fig. 2). The protein identification by mass spectrometry of W12 revealed a mixture of proteins as follows (Table 5): the B or D chain of hemoglobin and fatty acid-binding protein (FABP). Sayd et al. [54] reported that FABP may be a marker for a low $\mathrm{L}^{*}$ value in meat. However, these authors studied soluble proteins extracted from muscles. In the present study, the B chain of hemoglobin was found in the drip loss. Sayd et al. [54] found more hemoglobin in meat classified as belonging to the dark group, which is also characterized by increased oxidative metabolism. These authors also suggested that the higher abundance of hemoglobin may be linked to higher blood flow in muscles, higher hemoglobin content in the blood, and/or degree of bleeding. Thus, we can hypothesize that PSE meat is more prone to release these soluble proteins. The present study showed that the higher abundance of these proteins in the drip loss was related to the lightness of meat (Tables 1, 4). FABP was the second protein identified by mass spectrometry in the $\mathrm{W} 12$ band. Functionally, FABP is an intracellular protein that transports fatty acids from the cell membrane to sites of fatty acid oxidation, phospholipid synthesis, or 
Table 4 Quantification of soluble proteins in the drip loss from the Longissimus thoracis muscle of normal, PSE, and acid meat (Mean value $\pm \mathrm{SD}$ of three or four separate samples)

\begin{tabular}{|c|c|c|c|c|}
\hline & \multicolumn{4}{|l|}{ Meat quality } \\
\hline & Normal & PSE & Acid & $P$ \\
\hline $\mathrm{PHb} / \mathrm{PHbK}$ & $7.27 \pm 0.57$ & $6.60 \pm 0.96$ & $6.80 \pm 0.35$ & NS \\
\hline PFK & $0.97 \pm 0.39$ & $1.16 \pm 0.12$ & $1.23 \pm 0.06$ & NS \\
\hline AMPDA & $1.10 \pm 0.18$ & $1.13 \pm 0.15$ & $1.13 \pm 0.06$ & NS \\
\hline PGM & $6.75 \pm 0.39$ & $7.30 \pm 0.17$ & $7.03 \pm 0.15$ & 0.09 \\
\hline PK/PGI & $8.90 \pm 0.27$ & $9.40 \pm 0.36$ & $9.13 \pm 1.17$ & NS \\
\hline EN & $11.90 \pm 0.32$ & $11.80 \pm 0.10$ & $12.13 \pm 0.91$ & NS \\
\hline CK/PGAK & $9.75 \pm 0.54$ & $10.07 \pm 0.55$ & $7.83 \pm 3.49$ & NS \\
\hline ALD & $10.67 \pm 0.31$ & $11.10 \pm 0.78$ & $11.43 \pm 1.14$ & NS \\
\hline GAPDH/LDH & $15.05 \pm 0.39$ & $14.80 \pm 1.06$ & $14.77 \pm 0.90$ & NS \\
\hline PGAM & $7.20 \pm 0.41$ & $6.70 \pm 0.17$ & $6.80 \pm 0.30$ & NS \\
\hline TPI & $3.90 \pm 0.14$ & $3.73 \pm 0.06$ & $4.03 \pm 0.58$ & NS \\
\hline $\mathrm{Mb}$ & $3.25 \pm 0.17$ & $3.30 \pm 0.10$ & $3.33 \pm 0.51$ & NS \\
\hline W12 & $0.10^{\mathrm{b}} \pm 0.00$ & $0.87^{\mathrm{a}} \pm 0.31$ & $0.63^{\mathrm{a}, \mathrm{b}} \pm 0.50$ & 0.03 \\
\hline
\end{tabular}

a,b Means with different superscript show significant differences $(P \leq 0.05)$. The following abbreviations are used $P H b / P H b K$ phosphorylase b/phosphorylase b kinase, $P F K$ phosphofructokinase, AMPDA AMP deaminase $P G M$ phosphoglucomutase, $P K / P G I$ pyruvate kinase/phosphoglucose isomerase, $E N$ enolase, $C K / P G A K$ creatine kinase/phosphoglycerate kinase, $A L D$ aldolase, GAPDH/LDH glyceraldehyde-3-phosphate dehydrogenase/lactate dehydrogenase, PGAM phosphoglycerate mutase, TPI triosephosphate isomerase, $M b$ myoglobin

Table 5 LC-MS/MS identification of W12 spots in the drip loss from the Longissimus thoracis muscle

\begin{tabular}{|c|c|c|c|c|c|}
\hline Sequence reference ${ }^{\mathrm{a}}$ & Protein name ${ }^{a}$ & $\begin{array}{l}\text { Mascot } \\
\text { score }^{b}\end{array}$ & $\begin{array}{l}\text { Sequence } \\
\text { coverage }(\%)^{\mathrm{c}}\end{array}$ & $\begin{array}{l}\mathrm{Nb} \text { of peptide } \\
\text { matches }{ }^{\mathrm{d}}\end{array}$ & Th. MW Da \\
\hline gil809283 gil809285 & B or D chain, porcine hemoglobin & 348 & 78 & 14 & 16,025 \\
\hline Gil2143386 & $\begin{array}{l}\text { Fatty acid-binding protein } \\
\text { [Sus scrofa] }\end{array}$ & 86 & 9 & 1 & 14,740 \\
\hline
\end{tabular}

\footnotetext{
${ }^{a}$ Protein names and accession numbers were derived from the Swiss-Prot database

b The MASCOT baseline significant score is 67

c Percent of coverage of the entire amino acid sequence

${ }^{\mathrm{d}}$ Number of matched peptides in the database search

e Theoretical MW recorded in the mammalian taxonomy NCBI database and observed MN (calculated from the spot position on the gel)
}

triacylglycerol synthesis. Heart FABP (H-FABP) is expressed predominantly in muscle cells, and adipocyte FABP (A-FABP) is expressed almost exclusively in adipocytes. H-FABP expression is clearly higher in an oxidative muscle than in a glycolytic muscle. Significant associations between genetic variation at the A-FABP and H-FABP gene loci (FABP4 and FABP3) and intramuscular fat content (IMF) have been identified [55, 56]. Other studies, however, do not show clear associations between the genetic variance of FABP3 and IMF [57-60].

Correlation between muscle protein and quality traits

The analysis of correlation between muscle protein and meat quality traits showed that the $\mu$-calpain $(80 \mathrm{kDa}$ ) band was negatively correlated with $\mathrm{pH}_{1} \quad(r=-0.70$ and $\left.P_{\alpha} \leq 0.05\right), \mathrm{pH}_{24}\left(r=-0.54\right.$ and $\left.P_{\alpha} \leq 0.05\right)$, and ultimate $\mathrm{pH}\left(r=-0.56\right.$ and $\left.P_{\alpha} \leq 0.05\right)$. These results were consistent with those reported by Bee et al. [10] who showed that $\mu$-calpain is less abundant in meat with higher $\mathrm{pH}$ values. In the present study, the ultimate $\mathrm{pH}$ was also negatively correlated with desmin $(53 \mathrm{kDa})(r=-0.60$ and $P_{\alpha} \leq 0.05$ ), which was in accordance with the study reported by Bee et al. [10], who reported lower degradation of desmin in meat with lower $\mathrm{pH}$ values. These authors suggested that the autolysis of $\mu$-calpain occurs earlier in meat with faster rates of $\mathrm{pH}$ decline, which may explain the lower degradation of desmin in meat with low $\mathrm{pH}$ values. Meat with low $\mathrm{pH}$ values is characterized by a pale color, thus resulting a higher $\mathrm{L}^{*}$ value (Table 1 ), which explains 
the positive correlation between $\mu$-calpain and $\mathrm{L}^{*}$ ( $r=0.62$ and $P_{\alpha} \leq 0.05$ ). A significant relationship between $\alpha$-actinin and $\mathrm{pH}_{1}\left(r=0.63\right.$ and $\left.P_{\alpha} \leq 0.05\right)$ was also observed. Pospiech et al. [61] mentioned that the release of $\alpha$-actinin from the $\mathrm{Z}$ disk may contribute to the increased meat tenderness and water-holding capacity.

M8 (31 kDa) and M10 (29 kDa) were negatively correlated with glycogen (M8, $r=-0.69$ and $P_{\alpha} \leq 0.05$; M10 $r=-0.52$ and $\left.P_{\alpha} \leq 0.05\right)$ and GP (M8, $r=-0.68$ and $P_{\alpha} \leq 0.05 ; \mathrm{M} 10, r=-0.52$, and $\left.P_{\alpha} \leq 0.05\right)$, and positively correlated with ultimate $\mathrm{pH}(\mathrm{M} 8, r=0.80$ and $P_{\alpha} \leq 0.05$; M10, $r=0.58$ and $\left.P_{\alpha} \leq 0.05\right)$. Moreover, M8 (31 kDa) was negatively correlated with $\mathrm{L}^{*}(r=-0.64$ and $\left.P_{\alpha} \leq 0.05\right)$ and $\mathrm{b}^{*}\left(r=-0.53\right.$ and $\left.P_{\alpha} \leq 0.05\right)$, and positively correlated with juiciness $(r=0.67$ and $\left.P_{\alpha} \leq 0.05\right)$. As mentioned earlier, the M8 and M10 polypeptides are products of $\mathrm{CK}$ degradation and the lower abundance of M8 and M10 in meat may indicate a higher content of active CK. Van de Wiel and Zhang [9] observed a higher content of $\mathrm{CK}$ in meat with lower $\mathrm{pH}$ levels and they hypothesized that high $\mathrm{CK}$ levels cause rapid degradation of creatine phosphate (CP) and an increased rate of glycolysis, which, in turn, may cause a more rapid $\mathrm{pH}$ decline and muscle contraction, thus resulting in a high drip loss. High glycogen and PG are indicators of a faster rates of glycolysis and, in turn, a rapid decline of $\mathrm{pH}$ and pale color [39, 40], which was verified with the present results (Table 1).

TnC was less abundant in PSE and acid meat than in normal meat, and the opposite result was observed for TnI. Moreover, TnC was negatively correlated with drip loss ( $r=-0.52$ and $P_{\alpha} \leq 0.05$ ). TnC and TnI are involved in the regulation of muscle contraction, with antagonist effects. Thus, TnC and TnI were inversely correlated with meat quality traits such as $\mathrm{pH}_{1}$ (TnI, $r=-0.18$ and $P_{\alpha} \leq 0.05$; TnC, $r=0.52$ and $\left.P_{\alpha} \leq 0.05\right)$, ultimate $\mathrm{pH}$ (TnI, $r=-0.56$ and $P_{\alpha} \leq 0.05$; TnC, $r=0.76$ and $P_{\alpha} \leq 0.05$ ), color parameters L* (TnI, $r=0.40$ and $P_{\alpha} \leq 0.05$; TnC, $r=-0.78$ and $P_{\alpha} \leq 0.05$ ), $\mathrm{b}^{*}$ (TnI, $r=0.53$ and $P_{\alpha} \leq 0.05$; TnC, $r=-0.57$ and $\left.P_{\alpha} \leq 0.05\right)$, glycogen (TnI, $r=0.55$ and $P_{\alpha} \leq 0.05$; TnC, $r=-0.71$ and $P_{\alpha} \leq 0.05$ ), and GP (TnI, $r=0.64$ and $P_{\alpha} \leq 0.05$; TnC, $r=-0.60$ and $\left.P_{\alpha} \leq 0.05\right)$. The average TnC/TnI ratio was 1.41 for normal meat, 0.83 for PSE meat, and 0.70 for acid meat. These results suggested some regulation changes in the PSE and acid meat. Lin et al. [62] and Pospiech et al. [61] reported that TnI competes with TnT for the same binding sites on $\mathrm{TnC}$ and that the variation in binding affinity between $\mathrm{TnC}$ and $\mathrm{TnT}$, as modulated by $\mathrm{Ca}^{2+}$, may have an important role in a $\mathrm{Ca}^{+2}$-regulated mechanism of muscle contraction. Josell et al. [20] reported that the increased level of proteolysis is initiated by an increased rate of ATP degradation and rapid $\mathrm{pH}$ decline.
The significant correlation between tropomyosin and tenderness $\left(r=-0.69\right.$ and $\left.P_{\alpha} \leq 0.05\right)$ indicated an increase in meat tenderness together with an increased degree of tropomyosin degradation. Tropomyosin is also proteolyzed by cathepsin, which is more active at low $\mathrm{pH}$ levels, and confirms the aforementioned results of Josell et al. [18] and Miller et al. [45] who reported that meat with low $\mathrm{pH}$ levels is characterized by higher tenderness.

Myosin LC1 was positively correlated with ultimate $\mathrm{pH}$ ( $r=0.55$ and $\left.P_{\alpha} \leq 0.05\right)$ and negatively correlated with the $\mathrm{b}^{*}$ color parameter $\left(r=-0.53\right.$ and $\left.P_{\alpha} \leq 0.05\right)$. These data were in agreement with the results presented by Choi et al. [16] who reported that meat with faster glycolysis rates contain less myosin $\mathrm{LC} 1$ and they demonstrated that myosin LC isoforms can influence muscle glycolytic rate during the early postmortem period.

Correlation between drip loss proteins and quality traits

The analysis of correlation between proteins from drip loss and myofibrils highlighted specific associations. The soluble proteins from the drip loss showed less significant correlation with meat quality traits. In PSE meat, which is characterized by a rapid $\mathrm{pH}$ decline $\left(\mathrm{pH}_{1}\right)$, phosphoglucomutase (PGM), the enzyme of the glycolytic pathway involved in the interconversion between glucose-1-P and glucose-6-P, was more abundant (Table 4). Moreover, PGM was negatively correlated with $\mathrm{pH}_{1}(r=-0.68$ and $\left.P_{\alpha} \leq 0.05\right)$ and positively correlated with $\mathrm{L}^{*}(r=0.68$ and $\left.P_{\alpha} \leq 0.05\right)$ and drip loss $\left(r=0.80\right.$ and $\left.P_{\alpha} \leq 0.05\right)$. This higher quantity of PGM may suggest a potential increase in the mobilization of carbohydrates in postmortem degradation. $\mathrm{Xu}$ et al. [63] showed that PGM expression increased in the Large White breed, which is characterized by increased glycolytic metabolism, increased carbohydrate usage, and less lipid usage than the Meishan breed. These authors hypothesized that the intensive selection for lean muscle growth in Western pig breeds induces a shift in muscle metabolism toward a more glycolytic and less oxidative fiber type [64]. This phenomenon may be partially explained by the presence of pigs with higher PG and faulty meat in the studied breed of pig, which were intensively selected for lean muscle growth.

GAPDH/LDH was positively correlated with the $b^{*}$ color parameter $\left(r=0.65\right.$ and $\left.P_{\alpha} \leq 0.05\right)$. In some studies, GAPDH is considered as an indicator of the process of crushing the meat in cured and fermented products [61]. $\mathrm{LDH}$ is involved in the regeneration of postmortem NADH, which reduces metmyoglobin to deoxymyoglobin and maintains the color stability of muscle [13, 14]. The redox state of myoglobin is influenced by the $b^{*}$ color parameter [13]. Moreover, ALD was positively correlated with the $\mathrm{b}^{*}$ color parameter $\left(r=0.75\right.$ and $\left.P_{\alpha} \leq 0.05\right)$, but 
phosphorylase $\mathrm{b} /$ phosphorylase $\mathrm{b}$ kinase $(\mathrm{PHb} / \mathrm{PHbK})$ was negatively correlated with ALD $\left(r=0.76\right.$ and $\left.P_{\alpha} \leq 0.05\right)$. ALD and $\mathrm{PHb} / \mathrm{PHbK}$ are enzymes in the glycolytic pathway and their activity influences the rate of postmortem glycolysis. The ALD enzyme is applied in rabbit meat as an indicator of glycolytic metabolism [65]. A higher significant activity of these enzymes was observed by Ramirez et al. [65] in rabbits with higher glycolytic characteristics and higher $b^{*}$ values, which was consistent with the results of the present study (Tables 1, 4). Phosphorylase kinase $(\mathrm{PH})$ exists in two forms as follows: active a and non-active b. In PSE meat, the activity of PHa is higher than normal meat [66]. PSE meat is characterized by a pale color, which is also connected with the activity of the aforementioned enzymes.

Additionally, CK/PGAK was positively correlated with juiciness $\left(r=0.67\right.$ and $\left.P_{\alpha} \leq 0.05\right)$. CK is responsible for the conversion of creatine phosphate $(\mathrm{CP})$ into creatine and ATP. ATP production is necessary to keep the muscle in a relaxed state. When $70 \%$ of CP is degraded, then ATP is replenished by the degradation of glycogen. Glycolysis also produces lactate, $\mathrm{H}^{+}$, and heat, thus resulting in decreased $\mathrm{pH}$ levels and protein denaturation by approximately $20 \%$. Thus, the decline in $\mathrm{pH}$ depends on initial concentration of CP and glycogen [9, 67]. Van de Wiel and Zhang [9] suggested that higher CK levels cause a rapid degradation of $\mathrm{CP}$, which may, in turn, promote glycolysis, a more rapid $\mathrm{pH}$ decline, and muscle contraction, thereby, resulting in a high drip loss. Therefore, we hypothesize that a higher abundance of CK in drip loss indicates a lower content of CK in meat, which causes a slower degradation of $\mathrm{CP}$ and, consequently, the normal course of maturation. It is well known that such meat is juicier, which was verified by the present study (Table 2).

\section{Conclusions}

The results of the present study confirm a lower technological quality of PSE and acid meat. From a sensory point of view, PSE meat was characterized by lower color intensity and acid meat was characterized by the lowest levels of juiciness. The muscle protein profile showed a significantly a higher quantity of $\mu$-calpain in PSE and acid meat compared to normal meat. Additionally, lower quantity of polypeptides with molecular sizes 31 and $29 \mathrm{kDa}$, which were products of CK degradation, was observed in faulty meat (meat with higher rates of glycolysis). The lower quantity of myofibrillar proteins (myosin LC1, TnT, and TnC) in meat with higher glycogen levels and lower $\mathrm{pH}$ levels showed higher rates of proteolysis due to the higher enzymatic proteolysis activity in these meats. TnC and TnI were associated with meat quality. Moreover, these results showed that $\mathrm{TnC} / \mathrm{TnI}$ ratio can be a pertinent marker of postmortem muscle metabolism and is related to the textural properties of meat. Furthermore, several soluble proteins from the drip loss were related to meat quality, especially PGM and the B chain of hemoglobin in PSE meat.

Open Access This article is distributed under the terms of the Creative Commons Attribution License which permits any use, distribution, and reproduction in any medium, provided the original author(s) and the source are credited.

\section{References}

1. Santé-Lhoutellier V, Engel E, Aubry L, Gatellier P (2008) Effect of animal (lamb) diet and meat storage on myofibrillar protein oxidation and in vitro digestibility. Meat Sci 79:777-783

2. Daroit DJ, Brandelli A (2008) Implications of skeletal muscle creatine kinase to meat quality. J Anim Feed Sci 17:285-294

3. Koohmaraie M, Kennick WH, Angelemier AF, Elgasim EA, Jones TK (1984) Effect of postmortem storage on cold-shortened bosine muscle: analysis by SDS-polyacrylamide gel electrophoresis. J Food Sci 49:290-291

4. Koohmaraie M, Kennick WH, Elgasim EA, Anglemier AF (1984) Effects of postmortem storage on muscle protein degradation: analysis by SDS-polyacrylamide gel electrophoresis. J Food Sci 49:292-293

5. Schäfer A, Rosenvold K, Purslow PP, Andersen HJ, Henckel P (2002) Physiological and structural events post mortem of importance for drip loss in pork. Meat Sci 61:355-366

6. Melody JL, Lonergan SM, Rowe LJ, Huiatt TW, Mayes MS, Huff-Lonergan E (2004) Early postmortem biochemical factors influence tenderness and water-holding capacity of three porcine muscles. J Anim Sci 82:1195-1205

7. Huff-Lonergan E, Lonergan SM (2005) Mechanisms of waterholding capacity of meat: the role of postmortem biochemical and structural changes. Meat Sci 71:194-204

8. Huff-Lonergan E, Lonergan SM (2007) New frontiers in understanding drip loss in pork: recent insights on the role of postmortem muscle biochemistry. J Anim Breed Genet 124(Suppl 1): $19-26$

9. van de Weil DFM, Zhang WL (2007) Identification of pork quality parameters by proteomics. Meat Sci 77:46-54

10. Bee G, Anderson AL, Lonergan SM, Huff-Lonergan E (2007) Rate and extent of $\mathrm{pH}$ decline affect proteolysis of cytoskeletal proteins and water-holding capacity in pork. Meat Sci 76:359-365

11. Wimmers K, Ngu NT, Jennen DGJ, Tesfaye D, Murani E, Schellander K, Ponsuksili S (2008) Relationship between myosin heavy chain isoform expression and muscling in several diverse pig breeds. J Anim Sci 86:795-803

12. Huff-Lonergan E, Zhang W, Lonergan SM (2010) Biochemistry of postmortem muscle: lessons on mechanisms of meat tenderization. Meat Sci 86:184-195

13. Mancini RA, Hunt MC (2005) Current research in meat color. Meat Sci 71:100-121

14. Kim YH, Keeton JT, Smith SB, Berghman LR, Savell JW (2009) Role of lactate dehydrogenase in metmyoglobin reduction and color stability of different bovine muscles. Meat Sci 83:367-382

15. Grześ B, Pospiech E, Kapelański W, Łyczyński A, Mikołajczak B, Iwańska E (2006) A comparison of properties of meat of various quality groups (RFN, RFN-s, PSE and ASE) obtained from first farrowing gilts. Anim Sci Pap Rep 24:99-104 
16. Choi YM, Ryu YC, Kim BC (2007) Influence of myosin heavyand light chain isoforms on early postmortem glycolytic rate and pork quality. Meat Sci 76:281-288

17. Choe JH, Choi YM, Lee SH, Shin HG, Ryu YC, Hong KC, Kim BC (2008) The relation between glycogen, lactate content and muscle fiber type composition, and their influence on postmortem glycolytic rate and pork quality. Meat Sci 80:355-362

18. Josell $\AA$, Martinson L, Tornberg E (2003) Possible mechanism for the effect of the $\mathrm{RN}^{-}$allele on pork tenderness. Meat Sci 64:341-350

19. Josell Å, Von Seth G, Tornberg E (2003) Sensory quality and the incidence of PSE of pork in relation to crossbreed and RN phenotype. Meat Sci 65:651-660

20. Josell Å, Enfält AC, Von Seth G, Lindahl G, Hedebro-Velander I, Anderson L, Lundström K (2003) The influence of RN genotype, including the new V199I allele, on the eating quality of pork loin. Meat Sci 65:1341-1351

21. Joo ST, Kauffman RG, Kim BC, Park GB (1999) The relationship of sarcoplasmic and myofibrillar protein solubility to colour and water-holding capacity in porcine longissimus muscle. Meat Sci 52:291-297

22. Borzuta K (1998) The study of variable methods' usefulness to lean meat content estimation in the Europ system. Rocz Inst Przem Mięs Tł 35:7-74 (in Polish)

23. Prange H, Juggrt L, Scharner E (1977) Untersuchungen zur Muskel fleischqualitaet beim Schwein. Archives Experiments Vet Med 30:235-248

24. Dalrymple RH, Hamm R (1973) A method for the extraction of glycogen and metabolites from a single muscle sample. J Food Technol 8:439-444

25. Bergmeyer HU (1974) Methods of enzymatic analysis. Academic Press, New York

26. Monin G, Sellier P (1985) Pork of low technological quality with a normal rate of muscle $\mathrm{pH}$ fall in the immediate post-mortem period: the case of the Hampshire breed. Meat Sci 13:49-63

27. Koćwin-Podsiadła M, Krzęcio E, Przybylski W (2006) Pork quality and methods of its evaluation: a review. Pol J Food Nutr Sci 15(56):241-248

28. Baryłko-Pikielna N, Kossakowska T, Baldwin Z (1964) Selection of the optimal method preparing beef and pork meat for sensory analysis. Rocz Inst Przem Mięs 1:111 (in Polish)

29. ISO 13299.2:1998. Sensory analysis-methodology-general guidance for establishing a sensory profile

30. Meilgaard M, Civille GV, Carr BT (1999) Sensory evaluation techniques, 3rd edn. CRC Press, Boca Raton

31. Bollag DM, Edestein SJ (1999) Protein methods. Wiley-Liss, Inc New York

32. AOAC (1974) Nitrogen in meat. Kjeldahl method. Official Method 928.08

33. Kajak K, Przybylski W, Jaworska D, Rosiak E (2007) Characteristics of technological quality, sensory profile and shelf-life of pork with different pH. Food Sci Technol Qual 1:26-34 (in Polish)

34. Kamiński S, Koćwin-Podsiadła M, Sieczkowska H, Help H, Zybert A, Krzęcio E, Antosik K, Brym P, Wójcik E, Adamczyk G (2010) Screening 52 single nucleotide polymorphisms for extreme value of glycolytic potential and drip loss in pigs. J Anim Breed Genet 127:125-132

35. Sieczkowska H, Koćwin-Podsiadła M, Zybert A, Krzęcio E, Antosik K, Kamiński S, Wójcik E (2010) The association between polymorphism of PKM2 gene and glycolytic potential and pork meat quality. Meat Sci 84:180-185

36. Rosenvold K, Petersen JS, Lwerke HN, Jensen SK, Therkildsen M, Karlsson AH, Moller HS, Andersen HJ (2001) Muscle glycogen stores and meat quality as affected by strategic finishing feeding of slaughter pigs. J Anim Sci 79:382-391
37. Monin G (2003) Abattage des porcs et qualité des carcasses et des viande. INRA Prod Anim 16:251-262

38. Hambrecht E, Eissen JJ, Verstegen MWA (2003) Effect of processing plant on pork quality. Meat Sci 64:125-131

39. Immonen K (2000) Bovine muscle glycogen concentration in relation to diet, slaughter and ultimate beef quality. PhD Dissertation. University of Helsinki, 64

40. Przybylski W, Urbańska I, Santé-Lhoutellier V, Jaworska D, Czarniecka-Skubina E, Wachowicz I, Kołożyn-Krajewska D, Kajak K, Niemyjski S (2007) Effect of residual glycogen on technological and sensory quality of pork. In: International congress of meat science and technology, Beijing, China, 5-10 August

41. Stefanon B, Floris R, Bragila S, Davoli R, Fontanesi L, Dall'Olio S, Graziosi G, Sismel P, Russo V (2004) A new approach in association study of single nucleotide polymorphism of genes for carcass and meat quality traits in commercial pigs. Ital J Anim Sci 3:177-189

42. Amills M, Vidal $\mathrm{O}$, Tomàs $\mathrm{A}$, Gil $\mathrm{M}$, Sànchez $\mathrm{A}$, Noguera JL (2005) Polymorphism of the pig 2,4-dienoyl CoA reductase 1 gene (DECR1) and its association with carcass and meat quality traits. J Anim Sci 83:493-498

43. Kamiński S, Brym P, Wójcik E (2009) A note on association between polymorphism within the 2,4-dienoyl CoA reductase gene (DECR1) and growth rate of Polish Landrace boars. J Anim Feed Sci 18:71-77

44. Van Oeckel MJ, Warnants N (2003) Variation of the sensory quality within the $\mathrm{m}$. longissimus thoracis et lumborum of PSE and normal pork. Meat Sci 63:293-299

45. Miller KD, Ellis M, Bidner B, McKeith F, Wilson ER (2000) Porcine Longissimus glycolytic potential level effects on growth performance, carcass, and meat quality characteristics. J Muscle Foods 11:169-181

46. Le Roy P, Elisen JM, Caritez JC, Talmant A, Juin H, Sellier P, Monin G (2000) Comparison between the three porcine RN genotypes for growth, carcass composition and meat quality traits. Genet Sel Evolut 32:165-186

47. Toldrá F, Flores M (2000) The use of muscle as predictors of pork meat quality. Food Chem 69:387-395

48. Kołczak T, Pospiech E, Palka K, Łącki J (2003) Changes of myofibrillar and centrifugal drip proteins and shear force of psoas major and minor and semitendinosus muscles from calves, heifers and cows during post-mortem ageing. Meat Sci 64:69-75

49. Ahn DH, Shimada K, Takahaschi K (2003) Relationship between weakening of Z-disks and liberation of phospholipids during post mortem ageing of pork and beef. J Food Sci 68:94-98

50. Lametsch R, Roepstorff P, Bendixen E (2002) Identification of protein degradation during postmortem storage of pig meat. J Agric Food Chem 50:5508-5512

51. Ho CY, Stromer MH, Robson RM (1994) Identification of the $30 \mathrm{kDa}$ polypeptide in post mortem skeletal muscle as a degradation product of troponin-T. Biochimie 76:369-375

52. Gil M, Guerrero L, Sarraga C (1999) The effect of meat quality, salt and ageing time on biochemical parameters of dry-cured Longissimus dorsi muscle. Meat Sci 51:329-337

53. Pérez AS, Ruiz AG (2003) Separation and identification of sarcoplasmic proteins from hams from three white pigs crosses containing Duroc. Eur Food Res Technol 216:193-198

54. Sayd T, Morzel M, Chambon C, Franck M, Figwer P, Larzul C, Le Roy P, Monin G, Chérel P, Laville E (2006) Proteome analysis of the sarcoplasmic fraction of pig semimembranosus muscle: implications on meat color development. J Agric Food Chem 54:2732-2737

55. Gerbens F, Jansen A, Van Erp AJM, Harders F, Meuwissen THE, Rettenberger G, Veerkamp JH, Te Pas MFW (1998) The adipocyte fatty acid-binding protein locus: characterization and 
association with intramuscular fat content in pigs. Mamm Genome 9:1022-1026

56. Gerbens F, Van Erp AJM, Harders FL, Verburg FJ, Meuwissen THE, Veerkamp JH, Te Pas MFW (1999) Effect of genetic variants of the heart fatty acid-binding protein gene on intramuscular fat and performance traits in pigs. J Anim Sci 77:846-852

57. Nechtelberger D, Pires V, Sölkner J, Stur I, Brem G, Mueller M, Mueller S (2001) Intramuscular fat content and genetic variants at fatty acid-binding protein loci in Austrian pigs. J Anim Sci 79: 2798-2804

58. Urban T, Mikolasova R, Kuciel J, Ernst M, Ingr I (2002) A study of association of the FABP3 genotypes with fat and meat production of pigs. J Appl Genet 43:505-509

59. Árnyasi M, Grindflek E, Jávor A, Lien S (2006) Investigation of two candidate genes for meat quality traits in a quantitative trait locus region on SSC6: the porcine short heterodimer partner and heart acid binding protein genes. J Anim Breed Genet 123:198-203

60. Brandstetter AM, Sauerwein H, Veerkamp JH, Geay Y, Hocquette JF (2002) Effects of muscle type, castration, age and growth rate on H-FABP expression in bovine skeletal muscle. Livest Prod Sci 75:199-208

61. Pospiech E, Grześ B, Elminowska-Wenda G (2011) Protein changes. In: Pisula A, Pospiech E (eds) Meat-science and technology. Warsaw Life Sciences University, Poland (in Polish)
62. Lin TI, Mayadevi M, Dowben RM (1993) Modulation of troponin- $\mathrm{C}$ binding to troponin- $\mathrm{T}$ by $\mathrm{Ca} 2+$, probed by fluorescence. J Chin Chem Soc 40:607-619

63. Xu YJ, Jin ML, Wang LJ, Zhang AD, Zuo B, Xu DQ, Ren ZQ, Lei MG, Mo XY, Li FE, Zheng R, Deng CY, Xiong YZ (2009) Differential proteome analysis of porcine skeletal muscles between Meishan and Large White. J Anim Sci 87:2519-2527

64. Lefaucheur L, Milan D, Ecolan P, Le Callennec C (2004) Myosin heavy chain composition of different skeletal muscles in Large White and Meishan pigs. J Anim Sci 82:1931-1941

65. Ramirez JA, Oliver MA, Pla M, Guerrero L, Arino B, Blasco A, Pascual M, Gil M (2004) Effect of selection for growth rate on biochemical, quality and texture characteristics of meat from rabbits. Meat Sci 67:617-624

66. Koćwiń-Podsiadła M, Zybert A, Krzęcio E, Antosik K, Sieczkowska H (2009) Biochemical processes that control the quality of pork and beff. In: Świtoński M, Zwierzchowski L (eds) Genomics of cattle and pigs. WUP in Poznań, Poznań (in Polish)

67. Scheffler TL, Gerrard DE (2007) Mechanisms controlling pork quality development: the biochemistry controlling postmortem energy metabolism. Meat Sci 77:7-16 